\title{
Biomimetic versus Sintered Calcium Phosphates: The in vitro Behavior of Osteoblasts and Mesenchymal Stem Cells
}

\author{
Joanna-Maria Sadowska, M.Sc., t, Jordi Guillem-Marti, Ph.D., ${ }^{t, t}$ Edgar-Benjamin \\ Montufar, Ph.D., ${ }^{+, k}$ Montserrat Espanol, Ph.D., ${ }^{,+*}$ Maria-Pau Ginebra, Ph.D., ${ }^{+, *}, \|, *$ \\ †Biomaterials, Biomechanics and Tissue Engineering Group, Department of Materials \\ Science and Metallurgical Engineering, Technical University of Catalonia (UPC), Av. \\ Diagonal 647, Barcelona 08028, Spain, Tel.: (+34) 934017706
}

${ }^{\ddagger}$ Centre for Research in Nanoengineering, Technical University of Catalonia, C/ Pascual i Vila 15, Barcelona 08028, Spain, Tel.: (+34) 934015794

"Institute for Bioengineering of Catalonia, C/ Baldiri Reixac 10-12, Barcelona 08028, Spain, Tel.: (+34) 934039706

${ }^{\S}$ Current address: CEITEC - Central European Institute of Technology, Brno University of Technology, Purkyňova 656/123, 61200 Brno, Czech Republic.

joanna.maria.sadowska@upc.edu,_ jordi.guillem.marti@upc.edu, eb.montufar@ceitec.vutbr.cz, montserrat.espanol@upc.edu, maria.pau.ginebra@upc.edu

*Corresponding author 
ABSTRACT: The fabrication of calcium phosphates using biomimetic routes, namely, precipitation processes at body temperature, results in distinct features compared to conventional sintered calcium phosphate ceramics, such as a high specific surface area and micro or nanometric crystal size. The aim of this paper is to analyze the effects of these parameters on cell response, focusing on two bone cell types: rat mesenchymal stem cells (rMSCs) and human osteoblastic cells (SaOS-2). Biomimetic calcium deficient hydroxyapatite (CDHA) was obtained by a low temperature setting reaction, and $\alpha$-tricalcium phosphate $(\alpha-\mathrm{TCP})$ and $\beta$ - tricalcium phosphate $(\beta-\mathrm{TCP})$ were subsequently obtained by sintering CDHA either at $1400{ }^{\circ} \mathrm{C}$ or $1100{ }^{\circ} \mathrm{C}$. Sintered stoichiometric hydroxyapatite (HA) was also prepared using ceramic routes. The materials were characterized in terms of specific surface area, skeletal density, porosity and pore size distribution. SaOS-2 cells and rMSCs were seeded either directly on the surfaces of the materials or on glass coverslips subsequently placed on top of the materials to expose the cells to the CaP-induced ionic changes in the culture medium while avoiding any topography-related effects. CDHA produced higher ionic fluctuations in both cell culture media than sintered ceramics, with a strong decrease of calcium and a release of phosphate. Indirect contact cell cultures revealed that both cell types were sensitive to these ionic modifications, resulting in a decrease in proliferation rate, more marked for CDHA, this effect being more pronounced for rMSCs. In direct contact cultures, good cell adhesion was found on all materials, but whereas cells were able to proliferate on the sintered calcium phosphates, cell number was significantly reduced with time on biomimetic CDHA, which was associated to a higher percentage of apoptotic cells. Direct contact of the cells with biomimetic CDHA resulted also in higher ALP activity for both cell types as compared to sintered CaPs, indicating a promotion of the osteoblastic phenotype. 


\section{INTRODUCTION}

Synthetic bone grafts represent an advantageous alternative to autographs and allographs from various points of view. ${ }^{1-3}$ On the one hand, because they are of synthetic origin, availability is not a concern. Moreover, they do not cause immunogenic reactions or disease transmission. However, despite all these advantages, the success of these synthetic bone grafts depends on their capacity to actively stimulate bone regeneration while maintaining a tight synchronization between bone formation and reabsorption.

Calcium phosphates have been extensively used as bone substitutes. ${ }^{4-6}$ Traditionally, they

are obtained by high temperature sintering routes. However, in recent years the potential of using more mild reaction conditions, i.e., biomimetic routes based on dissolution/precipitation reactions that occur at room or body temperature has been disclosed. ${ }^{7,8}$ The reason for this shift is to attempt to mimic the processes by which the human body fabricates the mineral phase in bone, which is also a calcium phosphate. Thus, using biomimetic routes, it is now possible to obtain nanostructured calcium deficient hydroxyapatite materials (CDHA) that are more similar to the mineral phase in bone in terms of morphology, texture, composition, specific surface area and crystallinity. It is hypothesized that, due to the higher reactivity resulting from the mentioned properties, this biomimetic hydroxyapatite, would be more closely recognized by autologous bone and would consequently undergo similar remodeling processes as bone.

The high reactivity of biomimetic CDHA has, however, direct implications when assessing the in vitro cell response to this material. In previous studies, we showed that biomimetic CDHA significantly altered the ionic composition of the cell culture medium, ${ }^{9}$ affecting cellular behavior. This was demonstrated by growing cells on porous membranes (inserts) placed on top of the materials to allow ionic and protein exchanges through the membrane but preventing direct contact of cells with the material. ${ }^{10}$ Although the results could prove the 


\section{Tissue Engineering}

effect of the materials' reactivity, the effect of topography was not addressed in this study even if in vivo both, reactivity and topography contribute simultaneously. Moreover, the extent to which these changes could affect cellular behavior compared to traditional sintered calcium phosphates and the relative importance of the composition and surface texture must still be deciphered. Thus, the aim of this work is to investigate how biomimetic and sintered calcium phosphates alter the composition of the cell culture medium and the extent to which this change and the different textural properties affect cell behavior. For this purpose, two cell types that are relevant to the osteogenic process, namely, osteoblastic cells and mesenchymal stem cells, were cultured in direct contact with the surface of the materials and indirectly, i.e., in contact with the media modified by the material but without contacting the surface of the materials. For the indirect studies a novel strategy was explored, in which the cells were seeded on glass coverslips that were placed on top of the materials so that cells could continuously sense the average ionic environment caused by the diffusion of ions in and out of the material. The use of glass coverslips was preferred over the use of commercial Transwell systems not only for economic reasons but also because it allowed ease monitoring of the cells by optical microscopy. This is not possible when cells are grown on the porous membranes (inserts) of the Transwell systems.

Biomimetic CDHA $\left(\mathrm{Ca}_{9}\left(\mathrm{HPO}_{4}\right)\left(\mathrm{PO}_{4}\right)_{5}(\mathrm{OH})\right)$ obtained by hydrolysis of alpha tricalcium phosphate at $37{ }^{\circ} \mathrm{C}$ and sintered $\alpha$-TCP $\left(\alpha-\mathrm{a}_{3}\left(\mathrm{PO}_{4}\right)_{2}\right)$ and $\beta$-TCP $\left(\beta-\mathrm{a}_{3}\left(\mathrm{PO}_{4}\right)_{2}\right)$, both of

which were obtained by heat treatment of CDHA, were used as materials. The two sintered materials were chosen based on two considerations: 1) the sintering step results in materials with identical elemental compositions to CDHA (e.g., $\mathrm{Ca} / \mathrm{P}=1.5$ ), and 2) $\alpha$-TCP and $\beta$-TCP have been widely used as synthetic bone grafts. Moreover, an additional material was prepared as a control, i.e., stoichiometric hydroxyapatite $\left(\mathrm{Ca}_{10}\left(\mathrm{PO}_{4}\right)_{6}(\mathrm{OH})_{2}\right)$, which was obtained by sintering the same reagents used for the fabrication of CDHA. 


\section{MATERIALS AND METHODS}

\section{Material preparation}

Biomimetic CDHA discs were obtained by a cementitious reaction based on the hydrolysis of $\alpha$-TCP, as previously described. ${ }^{7}$ Briefly, $\alpha$-TCP powder containing $2 \mathrm{wt} \%$ of precipitated hydroxyapatite (PHA; Merck 2143, Merck, Darmstardt, Germany) was mixed with a $2.5 \mathrm{wt} \%$ aqueous solution of disodium hydrogen phosphate $\left(\mathrm{Na}_{2} \mathrm{HPO}_{4}\right.$; Panreac, Darmstadt, Germany) at a liquid to powder ratio of $0.65 \mathrm{~mL} / \mathrm{g}$. The paste was placed in Teflon molds to produce discs (15 mm diameter and $2 \mathrm{~mm}$ thickness), which were immersed in $37^{\circ} \mathrm{C}$ water for 7 days to ensure complete hydrolysis of the $\alpha$-TCP powder to CDHA. Afterwards, a thermal treatment was applied to the CDHA discs to obtain either $\beta$-TCP discs $\left(1100^{\circ} \mathrm{C} / 9 \mathrm{~h}\right.$, followed by slow cooling inside the furnace) or $\alpha$-TCP discs $\left(1400^{\circ} \mathrm{C} / 4 \mathrm{~h}\right.$, followed by quenching in air).

The $\alpha$-TCP powder used for the cementitious reaction was obtained heat-treating a 2:1 molar mixture of $\mathrm{CaHPO}_{4}$ (Sigma-Aldrich, St. Louis, MO, USA) and $\mathrm{CaCO}_{3}$ (Sigma-Aldrich, St. Louis, MO, USA) at temperatures up to $1400{ }^{\circ} \mathrm{C}$ for $15 \mathrm{~h}$, which was subsequently quenched in air. Afterwards, the $\alpha$-TCP was milled in a planetary ball mill (Pulverisette 6, Fritsch $\mathrm{GmbB})$ for $15 \mathrm{~min}$ at $450 \mathrm{rpm}$ using 10 agate balls $(\mathrm{d}=30 \mathrm{~mm})$.

Moreover, stoichiometric hydroxyapatite (HA) discs were prepared by mixing $\mathrm{CaHPO}_{4}$ and $\mathrm{CaCO}_{3}$ powders at a calcium/phosphorous molar ratio of 1.67 . Then, $0.6 \mathrm{~g}$ of the mixture was uniaxially compacted at $80 \mathrm{MPa}$ to obtain $15 \mathrm{~mm}$ discs. Afterwards, the discs were sintered at $1100{ }^{\circ} \mathrm{C}$ for $20 \mathrm{~h}$.

\section{Material characterization}

The dimensions and weights of the discs were recorded after the synthesis/sintering process. The phase composition of the discs was determined by X-ray diffraction (XRD, D8 


\section{Tissue Engineering}

Advance, Bruker, Karlsruhe, Germany). The diffractometer equipped with a $\mathrm{Cu} K_{\alpha} \mathrm{X}$-ray tube was operated at $40 \mathrm{kV}$ and $40 \mathrm{~mA}$. Data were collected in $0.02^{\circ}$ steps over the $2 \theta$ range of $10-80^{\circ}$, with a counting time of $2 \mathrm{~s}$ per step. For phase identification, the diffraction patterns were compared with the Joint Committee on Powder Diffraction Standards for HA (JCPDS 82-1943), $\alpha$-TCP (JCPDS 09-0348) and $\beta$-TCP (JCPDS 70-2065). Semi-quantitative X-ray diffraction analysis of the products was carried out using the reference intensity ratio (RIR) method. ${ }^{11}$ Infrared analyses were performed on a Perkin Elmer Frontier FT-IR spectrometer in the ATR mode to check the typical functional groups present in the samples. All spectra were obtained in the range of $225-4000 \mathrm{~cm}^{-1}$ with a spectral resolution of $4 \mathrm{~cm}^{-1}$ by averaging 32 scans. The microstructure of the samples was examined using Scanning Electron Microscopy (SEM, Zeiss Neon 40, Oberkochen, Germany) at an acceleration voltage of $5 \mathrm{kV}$ after the surface was coated with a thin gold-palladium layer. The surface roughness was characterized by confocal microscopy (Sensofar, PIm 2300), using a 50x magnification and a scanned area of $240 \times 180 \mu \mathrm{m}^{2}$. The specific surface area (SSA) was determined by nitrogen adsorption (ASAP 2020 Micromeritics, USA) using the BrunnauerEmmet-Teller (BET) method. The skeletal density was measured by helium picnometry (AccuPyc 133, Micrometrics, USA). Finally, the porosity and pore size distribution were measured by mercury intrusion porosimetry (MIP; Micromeritics AutoPore IV 9500, USA).

\section{Cell culture study}

Primary rat mesenchymal stem cells (rMSCs) were used to evaluate the osteoinductive potential of the different materials, e.g. their capacity to induce the differentiation of undifferentiated stromal cells to the osteoblastic phenotype. The effect of the materials on osteoblastic cells was assessed using human osteoblast-like SaOS-2 cells (ATCC, USA). 
Although SaOS-2 cells are an osteosarcoma cell line, their suitability as osteoblast cell model has been widely demonstrated. ${ }^{12-14}$

SaOS-2 cells were maintained in McCoy's medium (Sigma-Aldrich) supplemented with 10\% FBS, $2 \mathrm{mM}$ L-glutamine, penicillin/ streptomycin $(50 \mathrm{U} / \mathrm{mL}$ and $50 \mu \mathrm{g} / \mathrm{mL}$ respectively) and $20 \mathrm{mM}$ HEPES buffer, all from Invitrogen.

rMSCs were isolated from the tibias and femurs of Lewis rats at the Institute for Bioengineering of Catalonia (IBEC) as previously described. ${ }^{15}$ The mesenchymal stem cell phenotype was previously characterized by flow cytometry. ${ }^{16}$ Cells were expanded in Advanced DMEM supplemented with 10\% fetal bovine serum (FBS), 2 mM L-glutamine, penicillin/streptomycin (50 U/mL and $50 \mu \mathrm{g} / \mathrm{mL}$, respectively) and $20 \mathrm{mM}$ HEPES buffer, all from Invitrogen. Cells at passages 4-5 were used in all experiments.

\section{Direct contact cell cultures}

The discs were sterilized by immersion in $70 \%$ ethanol and rinsed three times with PBS. Then, the discs ( $\mathrm{n}=3$ per each independent experiment) were placed in 24 -well plates and incubated with the corresponding complete media overnight. Afterwards, $80 \times 10^{3}$ cells/well were seeded and incubated for 4 or 6 hours (SaOS-2 cells or rMSCs, respectively), and then cultured up to 7 days; the media was refreshed every day. Tissue culture polystyrene (TCPS) was used as control.

\section{Indirect contact cell cultures}

The cells were cultured in indirect contact with the calcium phosphate discs using glass coverslips $(\mathrm{d}=8 \mathrm{~mm})$ to determine the effect of ionic exchanges. For this purpose the coverslips were first sterilized by immersion in 70\% ethanol, rinsed three times with PBS, and then placed in 48-well plate and incubated with FBS for 4 hours. Subsequently, $20 \times 10^{3}$ cells (SaOS-2 cells) or $5 \times 10^{3}$ cells (rMSCs) were seeded on the coverslips and incubated 
overnight. The initial number of each type of cells was determined in a previous assay to prevent confluence and subsequent detachment from the glass coverslips at the end of the assay. The coverslips were then transferred to 24-well plates and placed on top of the sterilized and preconditioned calcium phosphate discs as shown in Figure S1 in the supplementary information (preconditioning was carried out as described in the direct contact assays). The discs remained stable on top of the samples throughout the assay. The cells were incubated for the same time periods as the direct cell cultures, and the media was refreshed every day. Glass coverslips on TCPS were used as the control.

\section{Cell proliferation}

The cells were lysed with $300 \mu \mathrm{L}$ of M-PER ${ }^{\circledR}$ (Mammalian Protein Extraction Reagent, Thermo Scientific, Waltham, MA, USA) after transferring the calcium phosphate discs (direct culture) or the coverslips (indirect cell culture) onto a new 24-well plate at each specified time. Cell proliferation was evaluated at 4 or 6 hours (SaOS-2 cells or rMSCs, respectively), 3 and 7 days of cell culture. At each time point, cells were lysed with $300 \mu l$ of MPER The cell number was evaluated using the Cytotoxicity Detection Kit LDH (Roche Applied Science, Penzberg, Germany), according to the manufacturer's instructions. The LDH activity was measured spectrophotometrically at $492 \mathrm{~nm}$ with PowerWave HT microplate reader (Bio-Tek Instruments, Inc.). ${ }^{17} \mathrm{~A}$ calibration curve with a decreasing number of cells was prepared to express the results as cell numbers. Finally, the results were expressed as a relative fold change compared to the cell number obtained on TCPS at 4 hours or 6 hours (SaOS-2 cells or rMSCs, respectively). The experiments were performed in triplicate.

\section{Cell differentiation}


The alkaline phosphatase (ALP) activity was quantified as a marker of osteogenic differentiation. ALP activity was determined in the same extracts used for the cell proliferation assay, which did not contain osteogenic factors, using a SensoLyte ${ }^{\circledR} p$ NPP Alkaline Phosphate Assay Kit (AnaSpec Inc., CA, USA), according to the manufacturer's instructions. The ALP levels were measured spectrophotometrically at $405 \mathrm{~nm}$ using a PowerWave HT microplate reader (Bio-Tek Instruments, Inc.). The results were normalized to the number of cells obtained in the proliferation assay at each corresponding time point and divided by the assay incubation time. The experiments were performed in triplicate.

\section{Cell morphology}

Cell morphology in the direct contact test was observed by SEM (Zeiss Neon 40, Oberkochen, Germany) at each specified time point. The cell-seeded discs were washed in PBS (x3) and fixed in a $2.5 \%$ glutaraldehyde solution in PBS for $1 \mathrm{~h}$ at $4{ }^{\circ} \mathrm{C}$. Subsequently, the fixed samples were washed in PBS (x3) and dehydrated in a 50, 70, 90, 96 and 100\% ethanol series. Complete dehydration was achieved in hexamethyldisilazane (HMDS), and the discs were stored inside a desiccator. The dried discs were covered with a thin goldpalladium layer using vapor deposition (EMITECH K950X).

\section{Apoptosis/necrosis assay}

Flow cytometry analyses were performed to determine the cell death pathways for both the direct and indirect cell cultures on the CDHA samples. Briefly, either SaOS-2 cells or rMCSs were seeded on CDHA as described above (section 2.3.1. Direct contact cell culture and section 2.3.2. Indirect contact cell culture). After adhesion, the cells were detached with TrypLE (Invitrogen) and centrifuged at $300 \mathrm{rcf}$ for $5 \mathrm{~min}$, followed by rinsing with cold PBS. Subsequently, the cells were stained with Dead Cell Apoptosis Kit with annexin V-Alexa 


\section{Tissue Engineering}

Fluor 488 and Propidium Iodide (PI) (Invitrogen), according to the manufacturer's protocol. All incubations were performed in the dark. TCPS and glass coverslips were used as the controls for the direct and indirect contact cell cultures, respectively. Ten thousand events were analyzed on the Gallios Flow Cytometer (Beckman Coulter, Brea, CA, USA) by measuring the fluorescence emission at $530 \mathrm{~nm}$ (FL1) and $>575 \mathrm{~nm}$ (FL4) for annexin V and PI detection, respectively. The samples were analyzed using Summit 4.3 Software.

\section{Measurements of the $\mathrm{pH}$ and ion concentrations in the cell culture media}

The supernatants of the direct cell cultures were collected at each specified time point. Firstly, the $\mathrm{pH}$ was measured using a selective electrode (CRISON INSTRUMENTS, MultiMeter MM 41). Afterwards, the calcium and phosphorous concentrations in samples that had been diluted 10 -fold with $2 \%$ ultrapure nitric acid were quantified by inductively coupled plasma-optical emission spectrometry (ICP-OES, Perkin Elmer Optima 3200 RL).

\section{Statistical analysis}

The results are displayed as means \pm standard errors of the means. The Kruskal-Wallis nonparametric test, followed by the Mann-Whitney test with Bonferroni's correction were used to determine the statistically significant $(\mathrm{p}$-value $<0.05)$ differences between the means of the different groups.

\section{RESULTS}

\section{Material characterization}

The XRD results revealed that samples were phase-pure, except for $\beta$-TCP, where some additional peaks were visible that represented the presence of traces of hydroxyapatite ( $5 \mathrm{wt} \%$ ) (Supplementary information, Figure S2). Similarly, FTIR results confirmed the 


\section{Tissue Engineering}

presence of the typical vibrational bands in the different CaPs (Supplementary information, Figure S3). The skeletal densities measured by helium pycnometry were in agreement with the theoretical values (Table 1). All sintered materials ( $\alpha$-TCP, $\beta$-TCP and HA) exhibited low SSA values $\left(<1 \mathrm{~m}^{2} / \mathrm{g}\right)$, whereas CDHA presented higher SSA values (approximately 20 $\mathrm{m}^{2} / \mathrm{g}$ ). These results correlated very well with the microstructures observed by SEM. The morphology of CDHA (Figure 1a and 1b) consisted of aggregates of entangled nanometric plate-like-crystals (high magnification) that were formed around the initial $\alpha$-TCP particles. The presence of aggregates and nanometric plate-like crystals led to a bimodal pore size distribution, as determined by MIP, containing intra-aggregate pores in the 6- $200 \mathrm{~nm}$ range and inter-aggregate pores centered approximately $1 \mu \mathrm{m}$ (Figure 1c).

The sintering process applied to CDHA to obtain $\alpha$-TCP (Figure $1 \mathrm{~d}$ and e) and $\beta$-TCP (Figure $1 \mathrm{~g}$ and $\mathrm{h}$ ) led to a phase transformation accompanied by the growth and coalescence of the crystals within the original CDHA aggregates, resulting in smoother textures and the disappearance of the nanoscale porosity (Figure $1 \mathrm{f}$ and i). The $\alpha$-TCP and $\beta$-TCP discs showed polygonal crystals, with some protuberances in the case of $\beta$-TCP due to the lower sintering temperature, with the pores between the crystals resulting from the original interaggregate pores observed in CDHA. As a result, the microscale porosity increased, leading to a sharp monomodal pore size distribution centered at $2.6 \mu \mathrm{m}$, which was slightly narrower for $\alpha$-TCP due to the higher sintering temperature. Sintered HA (Figure $1 \mathrm{j}$ and $\mathrm{k}$ ) also consisted of smooth polygonal crystals, with a sharp monomodal pore size distribution (Figure 11) centered approximately at $1.7 \mu \mathrm{m}$. However, the microstructure was more heterogeneous than the other sintered materials because HA was produced by sintering a compacted mixture of $\mathrm{CaCO}_{3}$ and $\mathrm{CaHPO}_{4}$, with different granulometries. Similar values of the average roughness (Sa) were found for the different substrates as displayed in Table 1, which was consistent with the fact that the same starting powder and L/P ratios were used for their fabrication. In 
terms of total porosity, CDHA and HA presented the highest porosity values of approximately $50 \%$, whereas $\beta$-TCP and $\alpha$-TCP had porosities ranging between $\sim 30-40 \%$ (Table 1). As expected, the porosities of $\alpha$-TCP and $\beta$-TCP were inversely proportional to the sintering temperature.

\section{Cell proliferation}

The efficiency of SaOS-2 cell adhesion in direct cultures after 4 hours was similar in all CaPs, except for $\beta$-TCP, where cell adhesion was slightly higher (Figure $2 \mathrm{a}$ ). At days 3 and 7 , there was a decrease in the number of cells on CDHA, whereas the number of cells increased slightly on $\alpha$-TCP, $\beta$-TCP and HA, but at a much slower rate than on TCPS. Regarding the rMSCs, CDHA and HA showed reduced cell adhesion compared to the other CaPs (Figure 2b). Moreover, the number of rMSCs on $\beta$-TCP, and more markedly on CDHA, decreased with time. In contrast, the number of cells on $\alpha$-TCP increased with time, as it did also on HA, although at lower rate.

The morphological studies performed by SEM showed that both osteoblasts and mesenchymal stem cells were able to adhere on the different surfaces (Figures. 3 and 4). At 4 $\mathrm{h}$ of culture, there were no visible differences in SaOS-2 cell spreading and morphology on the various CaPs. There was a continuous increase in the number of SaOS-2 cells grown on all CaPs with time, except for CDHA, where only few cells were observed after 3 and 7 days (Figure $3 \mathrm{~b}$ and $\mathrm{c}$ ). At day 7, the highest SaOS-2 cell density was observed on $\alpha$-TCP (Figure 3f), where the cells formed a multilayer. The rMSCs (Figure 4) showed similar behaviors as the SaOS-2 cells. However, at $6 \mathrm{~h}$ of culture, the rMSCs were flatter and spread more than the SaOS-2 cells.

In the indirect cell cultures, the initial number of SaOS-2 cells for all $\mathrm{CaPs}$ was similar to TCPS and increased with culture time (Figure 2c). However, the cell growth rate for CDHA 
was slower than the other groups. Regarding the rMSCs, the initial cell number was similar for all CaPs (Figure 2d). For CDHA, the number of rMSCs increased at day 3, followed by a decrease at day 7. For $\beta$-TCP and HA, the cell number increased at day 3 and remained constant at day 7. $\alpha$-TCP produced constant cell growth with time, reaching even higher values than TCPS.

\section{Cell differentiation}

When the SaOS-2 cells were cultured directly on the substrates in the absence of osteogenic medium, different trends were observed for the different materials (Figure 5a). Although $\alpha$ TCP and $\beta$-TCP exhibited a maximum activity at day 3 , followed by a decrease at day 7 , showing similar or smaller values than the control (TCPS), the ALP activity values for cells grown on CDHA continued to increase at day 7 , reaching significantly higher values than the other substrates. As expected, the rMSCs had smaller ALP activity values than the SaOS-2 cells. At 6 h, ALP activity in the cells cultured on HA were two-fold higher than the other CaPs and the control (Figure 5d), but they decreased at 3 and 7 days; the same trend was observed for $\alpha$-TCP. Although the ALP activity began increasing on $\square$-TCP, it was markedly decreased at $7 \mathrm{~d}$. In contrast, rMSCs cultured on CDHA showed a continuous increase in ALP activity during the cell culture.

The ALP activity values for SaOS-2 cells in indirect contact were similar for the different CaPs at all time points (Figure 5c). Notably, these ALP activity values were slightly lower than the values obtained when cells were in direct contact with the substrates. In contrast, rMSCs in indirect contact did not show any ALP activity at 6 hours and 3 days (Figure $5 \mathrm{~d}$ ). Only low ALP activity levels were observed for HA, $\alpha$-TCP and TCPS at day 7.

Ionic exchange in the cell culture medium during the cell culture studies 
The variations in $\mathrm{pH}$ with time for the various CaPs in McCoy's and advDMEM cell culture media are presented in Figure $6 \mathrm{a}$ and $\mathrm{b}$, respectively. The initial $\mathrm{pH}$ values for McCoy's and advDMEM media were 7.4 and 7.6, respectively, and they increased after $6 \mathrm{~h}$ of incubation with the cells to 8.53 and 8.10, respectively. Regarding McCoy's medium, $\alpha-$ TCP and $\beta$-TCP exhibited similar trends as TCPS. CDHA and HA reduced the pH slightly at 6 hours. For the advDMEM medium, all CaPs exhibited similar behaviors as TCPS, except for CDHA, which reduced the $\mathrm{pH}$ at 6 hours.

The results of the variations in the $\mathrm{Ca}^{2+}$ and inorganic phosphate $\left(\mathrm{P}_{\mathrm{i}}\right)$ ion concentrations after the various materials were exposed to McCoy's media and advDMEM are summarized in Figure $6 \mathrm{c}-\mathrm{f}$. It is important to highlight that the chemical compositions of both media are slightly different, particularly in terms of the $\mathrm{Ca}^{2+}$ and $\mathrm{P}_{\mathrm{i}}$ contents. The initial $\mathrm{Ca}^{2}$ and $\mathrm{P}_{\mathrm{i}}$ concentrations of McCoy's medium were $1.17 \mathrm{mM}$ and $4.34 \mathrm{mM}$, respectively, whereas for AdvDMEM the concentrations were $1.87 \mathrm{mM}$ and $1.16 \mathrm{mM}$, respectively. The $\mathrm{Ca}^{2+}$ concentrations were not altered in the media that was in contact with $\alpha$-TCP and HA (Figure $6 \mathrm{c}$ and d.). In contrast, there was a strong decrease in the $\mathrm{Ca}^{2+}$ concentrations in both media that was in contact with CDHA and $\beta$-TCP, particularly for advDMEM. Regarding the $\mathrm{P}_{\mathrm{i}}$ concentrations, both HA and $\beta$-TCP decreased the levels in both media, whereas $\alpha$-TCP maintained it constant (Figure 6e and $\mathrm{f}$ ). In contrast, $\mathrm{P}_{\mathrm{i}}$ release was observed for CDHA, which was notably higher in advDMEM (Figure 6e) than in McCoy's medium (Figure 6f).

\section{Apoptosis/necrosis assay}

The cell death pathway involved in the CDHA samples was evaluated by flow cytometry. Figure 7 presents the contour diagrams of the annexin V-Alexa Fluor 488/ PI of SaOS-2 cells (Figure 7a, b, e, and f) and rMSCs (Figure 7c, d, g, and h) in direct and indirect cell cultures on CDHA with their corresponding controls (TCPS and glass coverslip, respectively). The 
bottom left quadrant of the cytograms represents viable cells, which are negatively stained for PI and Alexa Fluor 488-annexin V. Necrotic cells, which are PI-positive and Alexa Fluor 488-annexin V-negative, are located in the top left quadrant. The bottom right quadrant corresponds to apoptotic cells that are positively stained for Alexa Fluor 488-annexin V, but negatively stained for PI. Finally, the upper right quadrant represents late apoptotic cells, which show positive staining for both Alexa Fluor 488-annexin V and PI.

For the direct cell cultures, the percentage of viable cells on CDHA decreased compared to TCPS, where the percentage of viable cells was greater than $90 \%$. This decrease in cell viability was similar for both SaOS-2 cells and rMSCs. The percentages of apoptotic and late apoptotic SaOS-2 cells in contact with CDHA were $23.09 \%$ and $5.08 \%$, respectively. Lower percentages of necrotic SaOS-2 cells in direct contact with CDHA were detected. In contrast, for rMSCs the percentage of apoptotic cells in direct contact with CDHA was lower than the SaOS-2 cells, but there was an increase in the percentages of late apoptotic and necrotic cells.

For the indirect cell culture studies, the percentage of viable cells in CDHA was similar to TCPS for both cell types, with approximately $90 \%$ viability and similar percentages of apoptotic, late apoptotic and necrotic cells.

\section{DISCUSSION}

The objective of this study was to analyze the in vitro cell response of bone-related cells to biomimetic and high-temperature sintered calcium phosphates. The calcium phosphates compared differed not only in chemical phase, but also in the textural properties, which strongly affected their reactivity. The cell culture studies showed very different trends for the biomimetic CDHA and the sintered calcium phosphates, both when the cells were cultured directly on the surface of the materials or on glass coverslips placed on the substrates. 


\section{Tissue Engineering}

Cell proliferation was strongly reduced when cells were cultured in direct contact with all substrates in comparison to TCPS, more significantly for SaOS-2 cells (Figure 2). The most striking results were those obtained for biomimetic CDHA, where the cell number, both for SaOS-2 and rMSCs strongly decreased with time, even if the cells initially adhered $(6 \mathrm{~h})$ to a similar extent as on the other substrates. In rMSCs a decrease in cell number was observed also for $\beta$-TCP. In contrast, both cell types did proliferate on $\alpha$-TCP and HA, although at a slower rate than on TCPS.

SEM observations (Figures 3 and 4) revealed that both rMSCs and SaOS-2 cells were less spread on CDHA. Similar findings on MSCs attachment and proliferation on octacalcium phosphate substrates with similar morphologies to CDHA were reported in previous

studies. ${ }^{21-23}$ One possible explanation could be the sharp morphology of the mineral crystals, which might have hindered cell adhesion. However, microstructure and ionic exchange are intrinsically linked parameters, and to better understand the effect that the material-induced ionic fluctuations of the cell culture medium could have on cell response, ionic concentrations in the cell culture medium were monitored at the different time points.

The ionic composition of the cell culture media was altered to different extents by the different materials, depending not only on the composition and therefore the solubility of the different materials, but also on their textural properties, since an increase in the specific surface area and the presence of interconnect pores in the samples increases the surface available for reaction with the surrounding medium. Moreover, the modification in the ionic concentrations depended on the nature of cell culture medium, which had different initial concentrations of $\mathrm{Ca}^{2+}$ and $\mathrm{P}_{\mathrm{i} .}{ }^{10}$ This aspect is crucial, as fluctuations in the ionic environment have been reported to directly control cell function, and specifically osteoblast and MSC proliferation, in a dose-dependent manner. ${ }^{24-27}$ 


\section{Tissue Engineering}

The supplementation with HEPES buffer greatly helped to preserve relatively stable $\mathrm{pH}$ values of most of the materials. A pronounced and maintained calcium depletion from the culture medium was registered both for McCoy's and AdvDMEM media in presence of CDHA and, to a minor extent, $\beta$-TCP (Figure $6 \mathrm{c}$ and d). The $\mathrm{Ca}^{2+}$ levels remained unchanged for stoichiometric HA and $\alpha$-TCP. The uptake of $\mathrm{Ca}^{2+}$ was previously described for biomimetic calcium phosphates, such as octacalcium phosphate ${ }^{22,23}$, and CDHA. ${ }^{9,10,28,29}$ This behavior was attributed to the maturation process to stoichiometric HA that is more thermodynamically stable $\mathrm{e}^{30,31}$ and was fostered by the high SSA of the materials and the presence of non-apatitic domains on their crystal surface, giving them a higher reactivity than that of high-temperature sintered materials. ${ }^{30}$

The ionic reactivity of the different materials with cell culture media in terms of $\left[\mathrm{P}_{\mathrm{i}}\right]$ also varied depending on the material. $\mathrm{P}_{\mathrm{i}}$ release was registered for $\mathrm{CDHA}$, which could be explained by the replacement of $\mathrm{P}_{\mathrm{i}}$ ions on the CDHA crystal surface or lattice structure with ions available in the culture medium, typically carbonate, which is known to replace superficial phosphate. ${ }^{32}$ The highest $\mathrm{P}_{\mathrm{i}}$ release observed in advDMEM could be associated to the highest carbonate content in this culture medium compared to McCoy's medium. ${ }^{10}$ Interestingly, $\beta$-TCP, which is more soluble than CDHA and had a much smaller SSA sequestered both, $\mathrm{P}_{\mathrm{i}}$ and $\mathrm{Ca}^{2+}$ from the medium. This behavior could be explained by the dissolution and subsequent reprecipitation of $\mathrm{CaP}$ on the recessed regions of the material where supersaturation could most easily be maintained.

In the indirect contact studies, the SaOS-2 cells were able to proliferate on the glass coverslips placed on top of the substrates, in spite of the modifications of the ionic concentrations in the McCoy's culture medium caused by the different materials to varying extents. These results agree with previous studies that suggest that SaOS- 2 cells are quite robust in terms of ionic fluctuations. ${ }^{33}$ Thus, the effect on cell proliferation when compared to 


\section{Tissue Engineering}

TCPS was small on HA and $\alpha$-TCP, where the materials caused slight modifications in calcium and phosphorous concentrations in the cell culture medium, and no difference was observed on $\beta$-TCP, despite the stronger ionic fluctuations registered (decrease of both calcium and phosphate concentrations) (Fig. 6). A significant reduction on the proliferation rate was found only on CDHA, where a strong depletion of calcium and release of phosphate was observed. In contrast, a higher sensitivity to the ionic fluctuations was noticed in the rMSCs. Lower rates of cell proliferation were observed in the indirect culture for all materials except $\alpha$-TCP, the effects being more marked in the materials where the ionic fluctuations were more pronounced, i.e. beta TCP and especially CDHA. Particularly, for CDHA, although the number of cells increased at day 3 , it strongly decreased at day 7 . As in the case SaOS-2, this behavior might be associated to the concomitant decrease in $\mathrm{Ca}^{2+}$ and increase in Pi concentrations, which is in good agreement with previous studies which were reported to reduce cell proliferation both osteoblasts-like cells ${ }^{25}$ and MSCs. ${ }^{34}$

The particular decrease in the number of cells grown in contact with CDHA after the initial cell adhesion was further analyzed by flow cytometry using markers for apoptosis and necrosis to reveal the cell death pathway. The results showed that the direct contact of cells with CDHA induced apoptosis already after a $6 \mathrm{~h}$ interaction (Figure 7). rMSCs exhibited a more advanced apoptosis stage, with a permeabilized plasma membrane (late apoptosis), than the SaOS-2 cells (Figure 7d). Low levels of apoptosis were observed when the cells were cultured on coverslips in indirect contact with CDHA (Figure $7 \mathrm{f}$ and $\mathrm{h}$ ). This agrees with the results of cell proliferation under this condition (Figure 2c and d), where cell number increased for SaOS-2 and for rMSCs decreased only at 7 days of culture (Figure 2d). This suggests that the fluctuations in $\mathrm{Ca}^{2+}$ and $\mathrm{P}_{\mathrm{i}}$ impacted on cell proliferation at later stages after cell adhesion, as previously described, ${ }^{25,34}$ and that the induction of apoptosis after $6 \mathrm{~h}$ of cell culture was associated to the direct interaction with the substrate. 
The results of the cell differentiation experiments obtained measuring the ALP activity, ${ }^{35}$ showed very different trends depending on the test type (direct vs. indirect cell culture) (Figure 5). As expected, rMSCs presented less ALP activity than SaOS-2 cells. ${ }^{36}$ SaOS-2 cells in the indirect assays showed low and constant ALP levels, whereas the rMSCs had almost non-existent ALP activity. No differences were observed between the different materials, despite the marked differences in $\mathrm{Ca}^{2+}$ and $\mathrm{P}_{\mathrm{i}}$ concentrations in the respective cell culture media. The indirect study revealed that direct cell contact with the biomaterial surface and chemistry was a requisite for promoting osteoblast differentiation. This is very relevant for the in vivo application since it evidences that cell differentiation cannot be stimulated by the ionic fluctuations caused by materials in their vicinity. Thus, this prevents undesirable new bone formation in remote areas in a similar way as ectopic mineralization occurs due to the migration of osteoinductive molecules.

Notably higher ALP levels were measured in the direct contact assays, and significant differences were found for CDHA compared to the other materials. The ALP activity of SaOS-2 in direct contact with $\alpha$-TCP, $\beta$-TCP and HA was similar or lower than on TCPS (Figure 5a), whereas 4-fold ALP activity was recorded on CDHA, with respect to TCPS at day 7, in agreement with previous studies that reported high ALP activity of osteoblastic cells on CDHA. ${ }^{28}$ A continuous increase in ALP activity was also recorded for the rMSC cultured on CDHA, similarly to what was observed in other biomimetic substrates like octacalcium phosphate. $^{23}$ Noteworthy, this increase in ALP activity on CDHA samples in both types of cells coincided with a decrease in cell number. However, although the number of cells was low in these conditions, the ALP activity values were significant when compared to indirect studies where also a decrease in cell numbers was observed. A direct effect of topography cannot be excluded, as it has been identified as a parameter controlling differentiation in both mesenchymal and osteoblastic cells when cultured on inert materials like poly(methyl 
methacrylate), titanium or titanium oxide, ${ }^{37-42}$ This effect is associated to the increased cytoskeletal tension, which is known to drive osteogenesis. ${ }^{42,43}$ However, the situation is far more complex in highly reactive calcium phoshates. We have shown that the ionic exchange is magnified in materials with high specific surface area (Figure 6), and this may result in complex ionic gradients that are difficult to measure. Thus, it could seem contradictory that cells cultured on CDHA, which induced a strong decrease of $\mathrm{Ca}^{2+}$ in the cell culture medium, presented higher ALP activity, since it is known that $\mathrm{Ca}^{2+}$ has a stimulatory effect on the differentiation of MSC. ${ }^{15,26}$ However, one should expect that the uptake of calcium by the material, which results in a decrease in the average $\mathrm{Ca}^{2+}$ concentration in the cell culture medium, leads simultaneously to an increased $\mathrm{Ca}^{2+}$ concentration on the surface of the material, where the cells are located. This could contribute, together with the topographical cues, to the enhanced differentiation suggested by the higher ALP activity levels when the cells are cultured directly on the material surface.

\section{CONCLUSIONS}

The results obtained show that the distinct physicochemical features of biomimetic and ceramic calcium phosphates modified differently the composition of the culture media, this in turn affecting cellular behavior in terms of proliferation and differentiation, although to different extents for SaOS-2 and rMSC cells. The use of glass coverslips was useful to separately determine the effects of the ionic fluctuations and direct contact with the surface, although this approach has some limitations, since on the coverslips cells were not able to sense the ionic gradients that take place in the close vicinity of the surface. Overall, this work highlights the inherent limitations of static cell culture assays, particularly for the assessment of reactive materials such as biomimetic CDHA. The drastic changes in the ionic composition in contact with the cell culture media caused by the high specific surface area and the non- 
stoichiometry of these materials can potentially affect cell behavior to the extent that the materials could appear to be cytotoxic, even if they function well in vivo. Dynamic cell culture assays that more closely simulate the in vivo scenario might contribute to advance in this direction.

\section{Acknowledgments}

The authors acknowledge the Spanish Government for financial support through MAT201565601-R project, co-funded by the EU through European Regional Development Funds, and FPI scholarship of JMS; and the Generalitat de Catalunya for the 2014SGR-1333 project. MPG acknowledges the ICREA Academia award by the Generalitat de Catalunya.

\section{Disclosure Statement}

The authors declare no competing financial interest.

\section{References}

1. LeGeros, R.Z., LeGeros, J.P., Calcium Phosphate Bioceramics: Past, Present and Future. Key Eng Mater 242, 3, 2003.

2. Bohner, M., Calcium orthophosphates in medicine: From ceramics to calcium phosphate cements. Injury 31 Suppl 4, 37, 2000.

3. Vallet-Regi, M., Gonzalez-Calbet, J.M. Calcium phosphates as substitution of bone tissues. Prog Solid State Chem 32, 1, 2004. 
4. Hench, L.L. Bioceramics. J Am Ceram Soc 81(7), 1705, 2005.

5. LeGeros, R.Z. Calcium phosphate-based osteoinductive materials. Chem Rev 108(11), 4742, 2008.

6. Dorozhkin S.V., Epple, M. Biological and Medical Significance of Calcium Phosphates. Angew Chem Int Ed 41, 3130, 2002.

7. Ginebra, M.P., Fernández, E., De Maeyer, E.A., Verbeeck, R.M., Boltong, M.G., Ginebra, J., et al. Setting Reaction and Hardening of an Apatitic Calcium Phosphate Cement. J Dent Res 76(4), 905, 1997.

8. Habraken, W., Habibovic, P., Epple, M., Bohner, M. Calcium phosphates in biomedical applications: materials for the future? Mater Today 19(2), 69, 2015.

9. Gustavsson, J., Ginebra, M.P., Engel, E., Planell, J. Ion reactivity of calcium-deficient hydroxyapatite in standard cell culture media. Acta Biomater 7(12), 4242, 2011.

10. Gustavsson, J., Ginebra, M.P., Planell, J., Engel, E. Osteoblast-like cellular response to dynamic changes in the ionic extracellular environment produced by calciumdeficient hydroxyapatite. J Mater Sci Mater Med 23(10), 2509, 2012.

11. Chung, F.H. Quantitative Interpretation of X-Ray Diffraction Method, Patterns of Mixtures. I. Matrix-Flushing for Quantitative Multicomponent Analysis. J Appl Crystallogr $7,519,1974$.

12. Pautke, C., Schieker, M., Tischer, T., Kolk, A., Neth, P., Mutschler, W., et al. Characterization of osteosarcoma cell lines MG-63, Saos-2 and U-2 OS in comparison to human osteoblasts. Anticancer Res 6(24), 3743, 2004. 
13. Saldaña, L., Bensiamar, F., Boré, A., Vilaboa, N., In search of representative models of human bone-forming cells for cytocompatibility studies. Acta Biomater 12(7), 4210, 2011.

14. Czekanska, E.M., Stoddart, M.J., Richards, R.G., Hayes, J.S., In search of an osteoblast cell model for in vitro research. Eur. Cells Mater 24, 1, 2012.

15. González-Vázquez, A., Planell, J.A., Engel, E., Extracellular calcium and CaSR drive osteoinduction in mesenchymal stromal cells. Acta Biomater 6(10), 2824, 2014.

16. Aguirre, A., Planell, J.A., Engel, E., Dynamics of bone marrow-derived endothelial progenitor cell/mesenchymal stem cell interaction in co-culture and its implications in angiogenesis. Biochem Biophys Res Commun 2(400), 284, 2010.

17. Allen, M., Millett, M., Dawes, E., Rushton, N.; Lactate dehydrogenase activity as a rapid and sensitive test for the quantification of cell numbers in vitro. Clin Mater 4(16), 189, 1994.

18. Dorozhkin, S.V., Calcium Orthophosphates in Nature, Biology and Medicine. Materials 2(2), 399, 2009.

19. Carrodeguas, R.G., De Aza, S., $\alpha$-Tricalcium phosphate: synthesis, properties and biomedical applications. Acta Biomater 10(7), 3536, 2011.

20. Elliott, J.C., Structure and chemistry of the apatites and other calcium orthophosphates. Amsterdam: Elsevier, 1994.

21. Guo, H., Su, J., Wei, J., Kong, H., Liu, C. Biocompatibility and osteogenicity of degradable Ca-deficient hydroxyapatite scaffolds from calcium phosphate cement for bone tissue engineering. Acta Biomater 5(1), 268, 2009. 
22. Anada, T., Kumagai, T., Honda, Y., Masuda, T., Kamijo, R., Kamakura, S., et al. Dose-Dependent Osteogenic Effect of Octacalcium Phosphate on Mouse Bone Marrow Stromal Cells. Tissue Eng Part A 14(6), 965, 2008.

23. Danoux, C., Pereira, D., Döbelin, N., Stähli, C., Barralet, J., van Blitterswijk, C., et al. The Effects of Crystal Phase and Particle Morphology of Calcium Phosphates on Proliferation and Differentiation of Human Mesenchymal Stromal Cells. Adv Healthc Mater 5(14), 1775, 2016.

24. Dvorak, M.M., Siddiqua, A., Ward, D.T., Carter, D.H., Dallas, S.L., Nemeth, E.F., et al. Physiological changes in extracellular calcium concentration directly control osteoblast function in the absence of calciotropic hormones. Proc Natl Acad Sci USA 101(14), 5140, 2004;

25. Meleti, Z., Shapiro, I.M., Adams, C.S. Inorganic phosphate induces apoptosis of osteoblast-like cells in culture. Bone 27(3), 359, 2000.

26. Barradas, A.M., Fernandes, H.A., Groen, N., Chai, Y.C., Schrooten, J., van de Peppel, J., et al. A calcium-induced signaling cascade leading to osteogenic differentiation of human bone marrow-derived mesenchymal stromal cells. Biomaterials 33(11), 3205, 2012.

27. Danoux, C.B., Bassett, D.C., Othman, Z., Rodrigues, A.I., Reis, R.L., Barralet, J.E., et al. Elucidating the individual effects of calcium and phosphate ions on hMSCs by using composite materials. Acta Biomater 17, 1, 2015.

28. Engel, E., Del Valle, S., Aparicio, C., Altankov, G., Asin, L., Planell, J., et al. Discerning the role of topography and ion exchange in cell response of bioactive tissue engineering scaffolds. Tissue Eng Part A 14(8), 1341, 2008. 
29. Knabe, C., Driessens, F.C., Planell, J.A., Gildenhaar, R., Berger, G., Reif, D., et al. Evaluation of calcium phosphates and experimental calcium phosphate bone cements using osteogenic cultures. J Biomed Mater Res 52(3), 498, 2000.

30. Vandecandelaere, N., Rey, C., Drouet, C. Biomimetic apatite-based biomaterials: On the critical impact of synthesis and post-synthesis parameters. J Mater Sci Mater Med 23(11), 2593, 2012.

31. Rollin-Martinet, S., Navrotsky, A., Champion, E., Grossin, D., Drouet, C. Thermodynamic basis for evolution of apatite in calcified tissues. Am Mineral 98(1112), $2037,2013$.

32. Cazalbou, S., Combes, C., Eichert, D., Rey, C., Glimcher, M.J. Poorly crystalline apatites: evolution and maturation in vitro and in vivo. J Bone Miner Metab 22(4), $310,2004$.

33. Chou, Y.F., Huang, W., Dunn, J.C., Miller, T.A., Wu, B.M. The effect of biomimetic apatite structure on osteoblast viability, proliferation, and gene expression. Biomaterials 26(3), 285, 2005.

34. Liu, Y.K., Lu, Q.Z., Pei, R., Ji, H.J., Zhou, G.S., Zhao, X.L., et al. The effect of extracellular calcium and inorganic phosphate on the growth and osteogenic differentiation of mesenchymal stem cells in vitro: implication for bone tissue engineering. Biomed Mater 2(4), 25004, 2009.

35. Stein, G.S., Lian, J.B. Molecular mechanisms mediating proliferation/differentiation interrelationships during progressive development of the osteoblast phenotype. Endocr Rev 14(4), 424, 1993. 
36. Rodan, S.B., Imai, Y., Thiede, M.A., Wesolowski, G., Thompson, D., Bar-shavit, Z., et al. Characterization of a human osteosarcoma cell line (Saos-2 ) with osteoblastic properties. Cancer Res 47(18), 4961, 1987.

37. Dalby, M.J., McCloy, D., Robertson, M., Wilkinson, C.D., Oreffo, R.O. Osteoprogenitor response to defined topographies with nanoscale depths. Biomaterials 27(8), 1306, 2006.

38. Schneider, G.B., Zaharias, R., Seabold, D., Keller, J., Stanford, C. Differentiation of preosteoblasts is affected by implant surface microtopographies. J Biomed Mater Res A 69(3), 462, 2004.

39. Masaki, C., Schneider, G.B., Zaharias, R., Seabold, D., Stanford, C., Effects of implant surface microtopography on osteoblast gene expression. Clin Oral Implants Res 16(6), 650, 2005.

40. Schwartz, Z., Lohmann, C.H., Oefinger, J., Bonewald, L.F., Dean, D.D., Boyan, B.D. Implant Surface Characteristics Modulate Differentiation Behavior of Cells in the Osteoblastic Lineage. Adv Dent Res 13, 38, 1999.

41. Oh, S., Brammer, K.S., Li, Y.S.J., Teng, D., Engler, A.J., Chien, S., et al. Stem cell fate dictated solely by altered nanotube dimension. Proc Natl Acad Sci U S A 106, $2130,2009$.

42. McBeath, R., Pirone, D.M., Nelson, C.M., Bhadriraju, K., Chen, C.S. Cell shape, cytoskeletal tension, and RhoA regulate stem cell lineage commitment. Dev Cell 6, 483, 2004. 
43. Kilian, K.A., Bugarija, B., Lahn, B.T., Mrksich, M. Geometric cues for directing the differentiation of mesenchymal stem cells. Proc Natl Acad Sci U S A 107, 4872, 2010.

\author{
Address correspondence to: \\ Maria-Pau Ginebra, Ph.D. \\ Technical University of Catalonia \\ Biomaterials, Biomechanics and Tissue Engineering Group \\ Dept. Materials Science and Metallurgical Engineering \\ ETSEIB, Diagonal 647 \\ 08028 Barcelona, Spain \\ E-mail: maria.pau.ginebra@upc.edu \\ Tel. +34934017706
}


Table 1. Physicochemical properties of the calcium phosphates used in the study. (Average values \pm standard deviation are displayed for the experimental values) [18-20]

\begin{tabular}{|l|c|c|c|c|c|c|c|c|}
\hline Material & $\begin{array}{c}\text { Nominal } \\
\mathrm{Ca} / \mathrm{P} \\
\text { Ratio }\end{array}$ & $\begin{array}{c}\text { Solubility at } \\
37^{\circ} \mathrm{C} \\
\left(-\log \mathrm{K}_{\mathrm{ps}}\right)^{18,19}\end{array}$ & $\begin{array}{c}\text { Theoretic } \\
\text { al density } \\
{[\mathrm{g} / \mathrm{mL}]^{20}}\end{array}$ & $\begin{array}{c}\text { Diameter of the } \\
\text { discs }[\mathrm{mm}]\end{array}$ & $\begin{array}{c}\text { Roughness, } \\
\mathrm{Sa}[\mu \mathrm{m}]\end{array}$ & SSA $\left[\mathrm{m}^{2} / \mathrm{g}\right]$ & $\begin{array}{c}\text { Skeletal } \\
\text { density } \\
{[\mathrm{g} / \mathrm{mL}]}\end{array}$ & $\begin{array}{c}\text { Porosity } \\
{[\%]}\end{array}$ \\
\hline CDHA & 1.5 & $85.1^{*}$ & d.n.f. & $15.00 \pm 0.04$ & $3.12 \pm 0.44$ & $19.13 \pm 0.04$ & $2.84 \pm 0.03$ & 50.04 \\
\hline$\alpha$-TCP & 1.5 & 28.5 & 2.87 & $13.02 \pm 0.04$ & $4.15 \pm 0.88$ & $0.22 \pm 0.00$ & $2.78 \pm 0.02$ & 32.84 \\
\hline$\beta$-TCP & 1.5 & 29.6 & 3.07 & $12.97 \pm 0.09$ & $3.78 \pm 1.27$ & $0.71 \pm 0.00$ & $3.05 \pm 0.07$ & 42.73 \\
\hline HA & 1.67 & 117.2 & 3.15 & $14.00 \pm 0.02$ & $3.35 \pm 0.65$ & $0.54 \pm 0.03$ & $3.20 \pm 0.02$ & 47.09 \\
\hline
\end{tabular}

d.n.f. $=$ data not found

* Solubility at $25^{\circ} \mathrm{C}$ 


\section{FIGURE LEGENDS}

Figure 1. SEM images of the surfaces of CDHA $(a, b), \alpha-\operatorname{TCP}(d, e), \beta-\mathrm{TCP}(\mathrm{g}, \mathrm{h})$ and HA (j, k). Pore entrance size distribution curves obtained by MIP for CDHA (c), $\alpha$ - TCP (f), $\beta$-TCP (i) and HA (1).

Figure 2. Proliferation of SaOS-2 cells grown in direct (a) and indirect contact (c) with the CaPs after 4 hours, 3 days and 7 days. Proliferation of rMSCs in direct (b) and indirect contact (d) with CaPs after 4 hours, 3 days and 7 days. The results were expressed as relative fold changes compared to the cell number obtained on TCPS at 4 hours or 6 hours (SaOS-2 cells or rMSCs, respectively). At each time point, "a" indicates a significant difference $(\mathrm{P}<0.05)$ compared with $\mathrm{CDHA}$; "b" indicates a significant difference $(\mathrm{P}<0.05)$ compared with $\alpha$-TCP; "c" indicates a significant difference $(\mathrm{P}<0.05)$ compared with $\beta$-TCP; and $\mathrm{d}$ indicates a significant difference $(\mathrm{P}<0.05)$ compared with HA.

Figure 3. Morphology of SaOS-2 observed by SEM at 4 hours, 3 days and 7 days of cell culture on different CaPs. Scale bare denotes $20 \mu \mathrm{m}$.

Figure 4. Morphology of rMSCs observed by SEM at 4 hours, 3 days and 7 days of cell culture on different CaPs. Scale bar denotes $20 \mu \mathrm{m}$.

Figure 5. ALP activity in SaOS-2 cells grown in direct (a) and indirect contact (c) with CaPs after 4 hours, 3 days and 7 days. ALP activity in rMSCs grown in direct (b) and indirect contact (d) with CaPs after 4 hours, 3 days and 7 days. The results were normalized to their corresponding number of cells. At each time point, a indicates a significant difference $(\mathrm{P}<0.05)$ compared with $\mathrm{CDHA}$; b indicates a significant difference $(\mathrm{P}<0.05)$ compared with $\alpha$-TCP; $\mathrm{c}$ indicates a significant difference $(\mathrm{P}<0.05)$ 
compared with $\beta$-TCP; and d indicates a significant difference $(\mathrm{P}<0.05)$ compared with HA.

Figure 6. Evolution of $\mathrm{pH}$ values and calcium and phosphorous concentrations in the cell culture media when the cells were cultured on the different materials: McCoy's cell culture medium in presence of SaOS-2 cells (a, c, and e); advDMEM in the presence of rMSCs (b, d, and f). The black horizontal line indicates the starting experimental values for the $\mathrm{pH}, \mathrm{Ca}^{2+}$, and Pi in McCoy's medium (a, c, and e) and $\operatorname{advDMEM~(b,~d,~and~f).~}$ The $\mathrm{pH}$ values for $\alpha$-TCP are not visible in Figure 7a because they overlap with the values for $\beta$-TCP.

Figure 7. Apoptosis/ necrosis assay by flow cytometry. The graphs represent the cell death pathways for SaOS-2 cells (a, b, e, and f) or rMSCs (c, d, g, h) grown in direct or indirect cell culture with CDHA. Cells that were positively stained for annexin V-FITC and negatively stained for PI were considered apoptotic. Cells that were positively stained for both annexin V-FITC and PI were considered late apoptotic. Cells that were negatively stained for annexin V-FITC and positively stained for PI were considered necrotic. The percentage of each type of cells is presented in the corresponding square of each graph. 

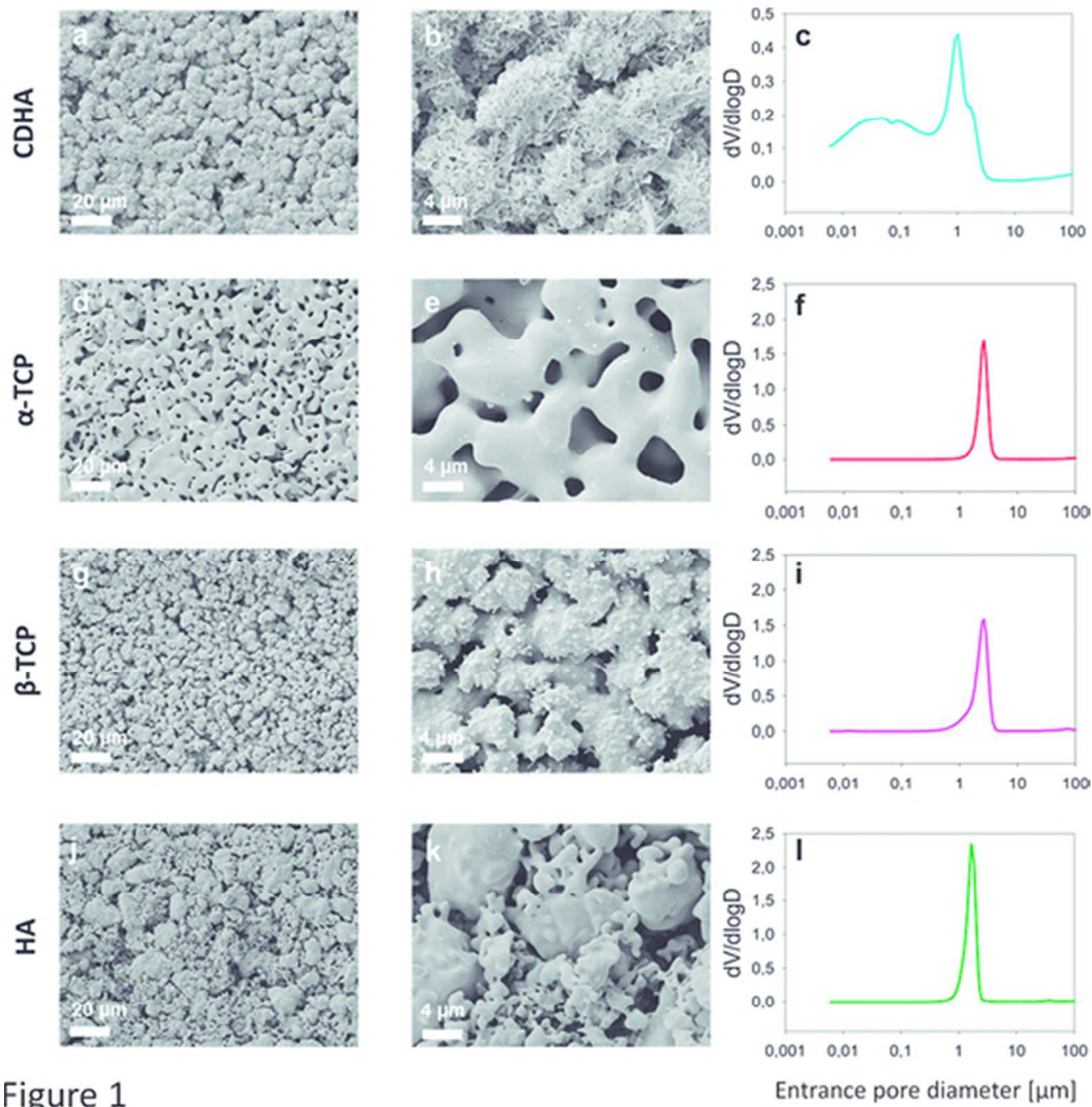

Figure 1

Figure 1. SEM images of the surfaces of CDHA (a, b), a- TCP $(d, e), \beta-\operatorname{TCP}(g, h)$ and HA (j, k). Pore entrance size distribution curves obtained by MIP for CDHA (c), a- TCP (f), $\beta$-TCP (i) and HA (I).

Figure 1

$48 \times 49 \mathrm{~mm}(300 \times 300 \mathrm{DPI})$ 

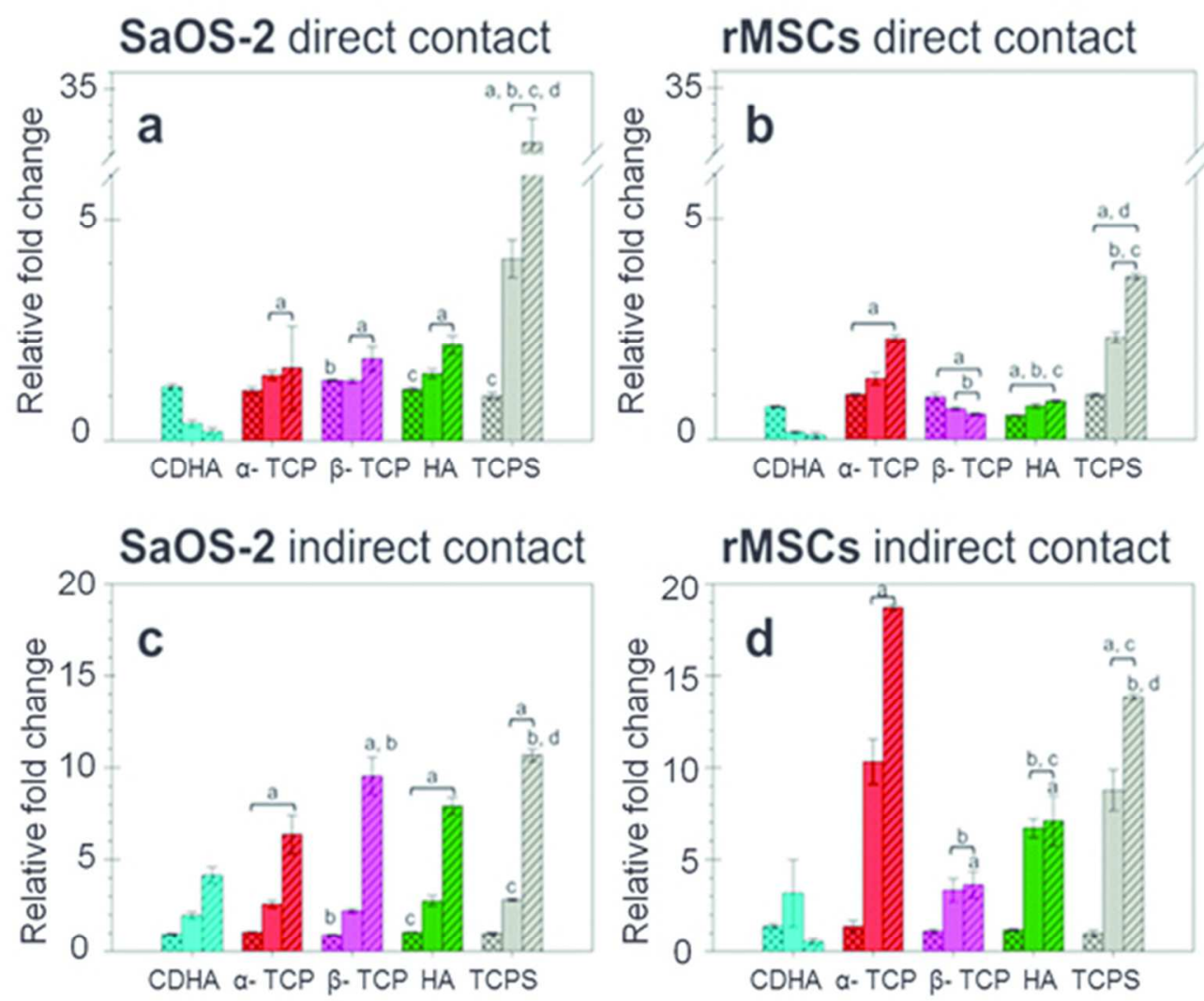

Figure 2

Figure 2. Proliferation of SaOS-2 cells grown in direct (a) and indirect contact (c) with the CaPs after 4 hours, 3 days and 7 days. Proliferation of rMSCs in direct (b) and indirect contact (d) with CaPs after 4 hours, 3 days and 7 days. The results were expressed as relative fold changes compared to the cell number obtained on TCPS at 4 hours or 6 hours (SaOS-2 cells or rMSCs, respectively). At each time point, "a" indicates a significant difference $(P<0.05)$ compared with $C D H A$; " $b$ " indicates a significant difference $(P<0.05)$ compared with a-TCP; " $C$ " indicates a significant difference $(P<0.05)$ compared with $\beta$-TCP; and $d$ indicates a significant difference $(P<0.05)$ compared with HA.

Figure 2 $48 \times 47 \mathrm{~mm}(300 \times 300 \mathrm{DPI})$ 


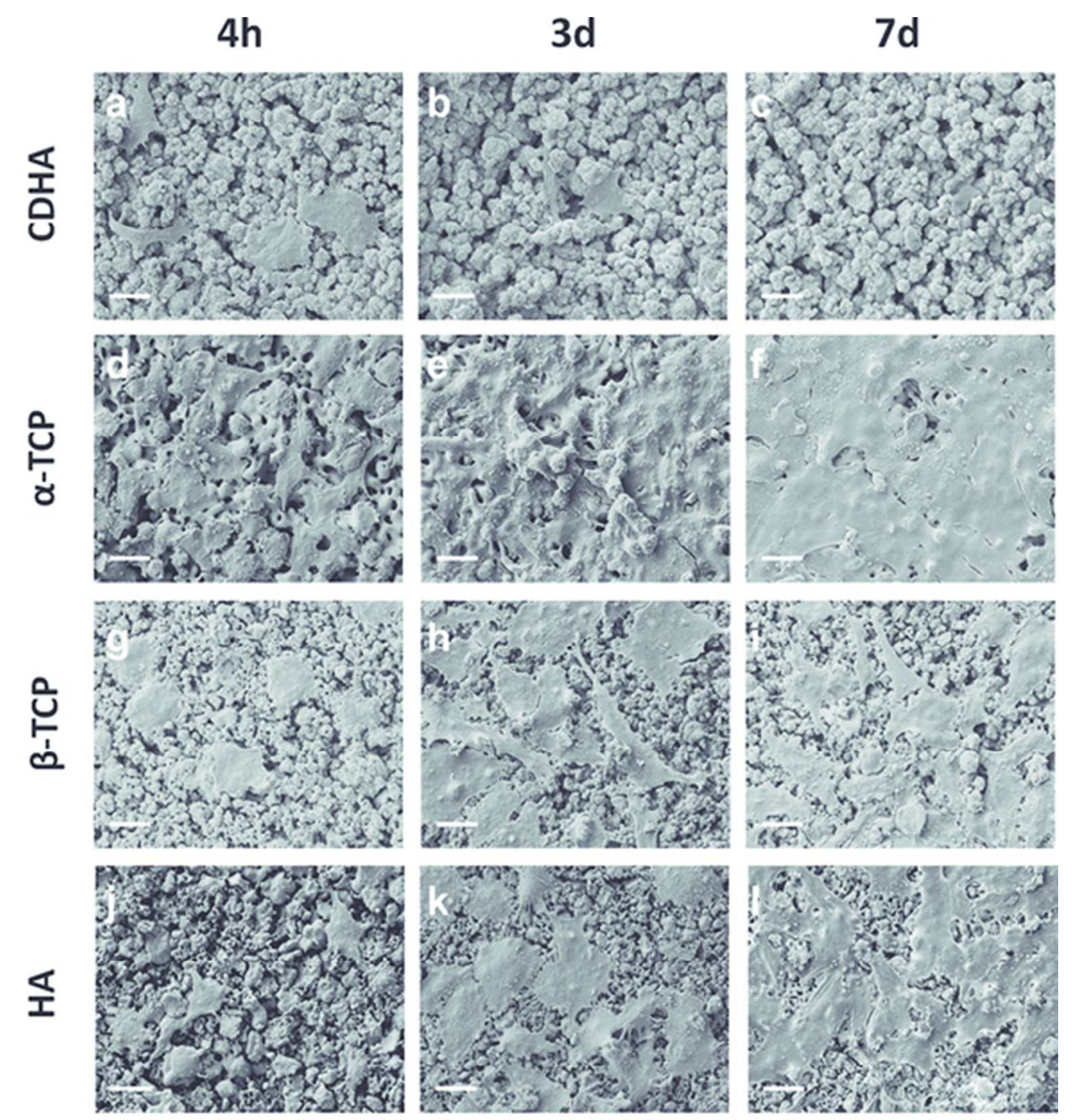

Figure 3

Figure 3. Morphology of SaOS-2 observed by SEM at 4 hours, 3 days and 7 days of cell culture on different CaPs. Scale bare denotes $20 \mu \mathrm{m}$.

Figure 3

$49 \times 54 \mathrm{~mm}(300 \times 300 \mathrm{DPI})$ 

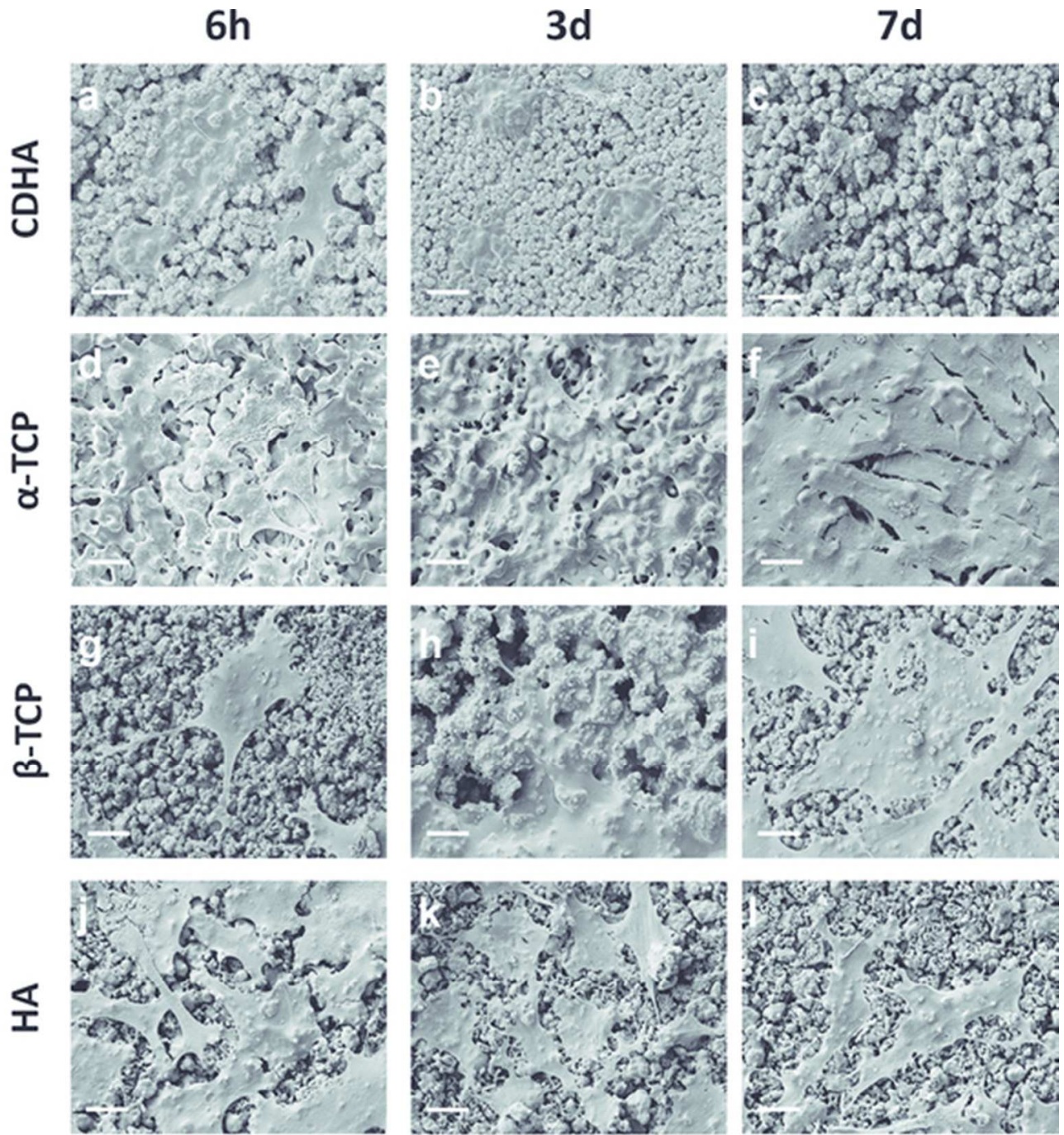

Figure 4

Figure 4. Morphology of rMSCs observed by SEM at 4 hours, 3 days and 7 days of cell culture on different CaPs. Scale bar denotes $20 \mu \mathrm{m}$.

Figure 4

$49 \times 55 \mathrm{~mm}(300 \times 300 \mathrm{DPI})$ 

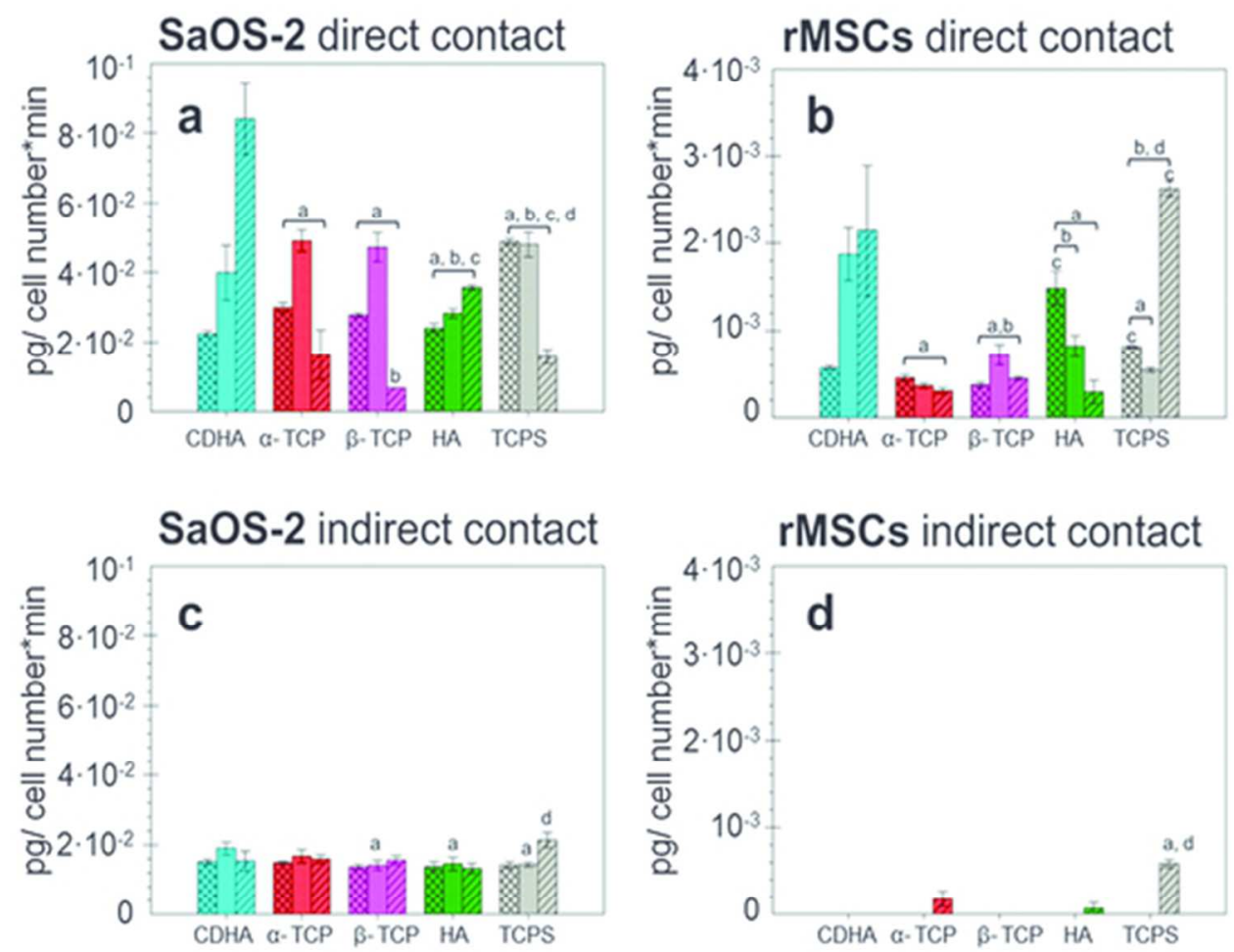

\section{Figure 5}

Figure 5. ALP activity in SaOS-2 cells grown in direct (a) and indirect contact (c) with CaPs after 4 hours, 3 days and 7 days. ALP activity in rMSCs grown in direct (b) and indirect contact (d) with CaPs after 4 hours, 3 days and 7 days. The results were normalized to their corresponding number of cells. At each time point, a indicates a significant difference $(P<0.05)$ compared with $C D H A ; b$ indicates a significant difference $(P<0.05)$ compared with a-TCP; $c$ indicates a significant difference $(P<0.05)$ compared with $\beta$-TCP; and $d$ indicates a significant difference $(P<0.05)$ compared with HA.

Figure 5

$48 \times 45 \mathrm{~mm}(300 \times 300$ DPI $)$ 


\section{$-\beta$-TCP $\nabla-\mathrm{HA} \diamond-\mathrm{TCPS}$ \\ advDMEM (rMSCs)}
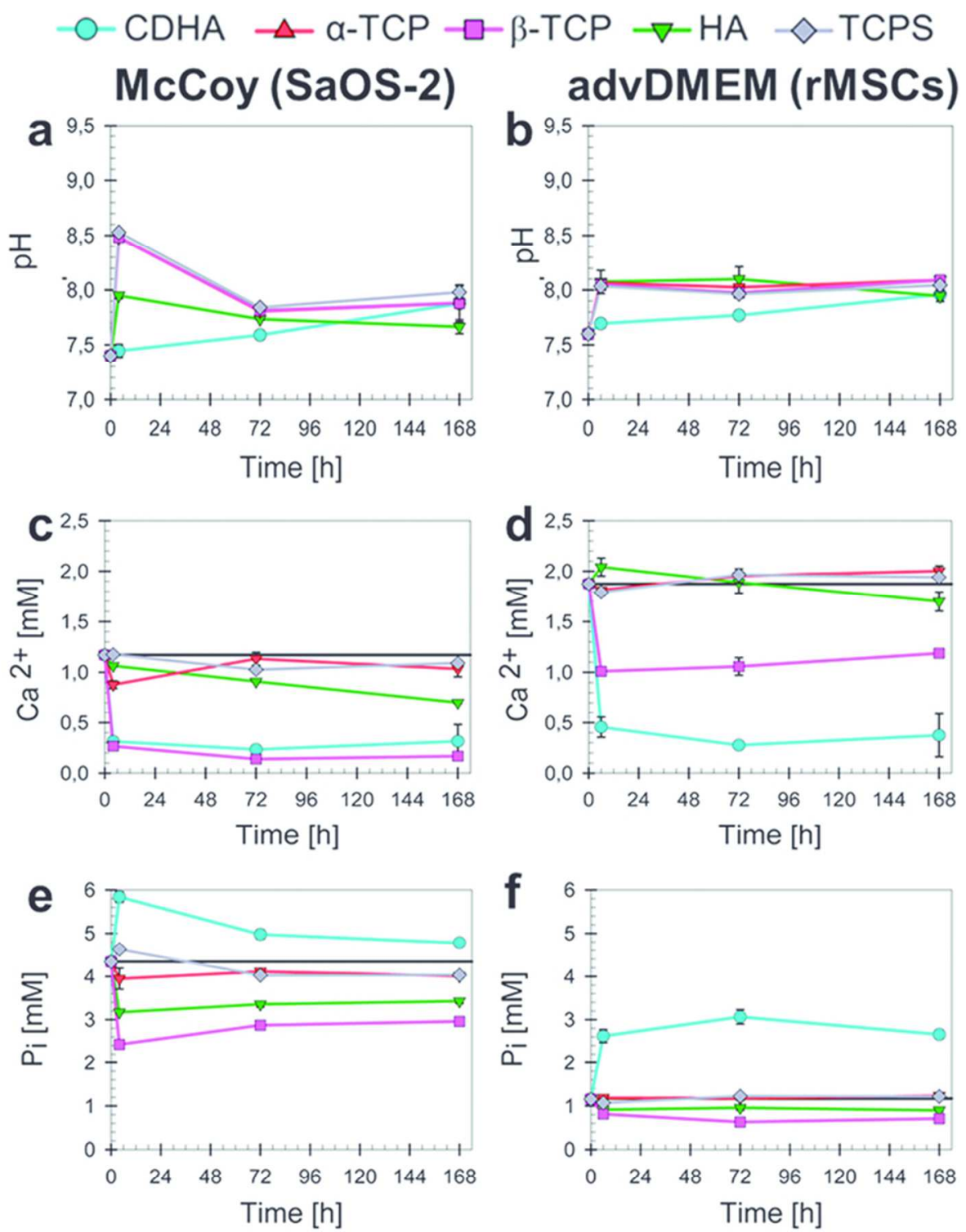

\section{Figure 6}

Figure 6. Evolution of $\mathrm{pH}$ values and calcium and phosphorous concentrations in the cell culture media when the cells were cultured on the different materials: McCoy's cell culture medium in presence of SaOS-2 cells ( $a, c$, and e); advDMEM in the presence of rMSCs (b, d, and f). The black horizontal line indicates the starting experimental values for the $\mathrm{pH}, \mathrm{Ca} 2+$, and $\mathrm{Pi}$ in McCoy's medium ( $\mathrm{a}, \mathrm{c}$, and e) and advDMEM (b, d, and $\mathrm{f}$ ). The $\mathrm{pH}$ values for a-TCP are not visible in Figure 7a because they overlap with the values for $\beta$-TCP.

Figure 6

$61 \times 79 \mathrm{~mm}(300 \times 300$ DPI $)$ 
Figure 7. Apoptosis/ necrosis assay by flow cytometry. The graphs represent the cell death pathways for SaOS-2 cells $(a, b, e$, and $f)$ or rMSCs $(c, d, g, h)$ grown in direct or indirect cell culture with CDHA. Cells that were positively stained for annexin V-FITC and negatively stained for PI were considered apoptotic. Cells that were positively stained for both annexin V-FITC and PI were considered late apoptotic. Cells that were negatively stained for annexin V-FITC and positively stained for PI were considered necrotic. The percentage of each type of cells is presented in the corresponding square of each graph.

Figure 7

$37 \times 28 \mathrm{~mm}(300 \times 300$ DPI $)$ 
Biomimetic versus Sintered Calcium Phosphates: The in vitro Behavior of Osteoblasts and Mesenchymal Stem Cells.

Joanna-Maria Sadowska, M.Sc., Jordi Guillem-Marti, Edgar-Benjamin Montufar, Montserrat Espanol, Maria-Pau Ginebra

\section{SUPPLEMENTARY INFORMATION}

\section{DIRECT CELL CULTURE}

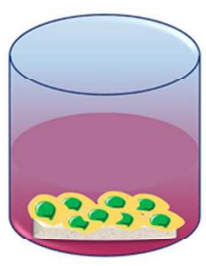

INDIRECT CELL CULTURE

a
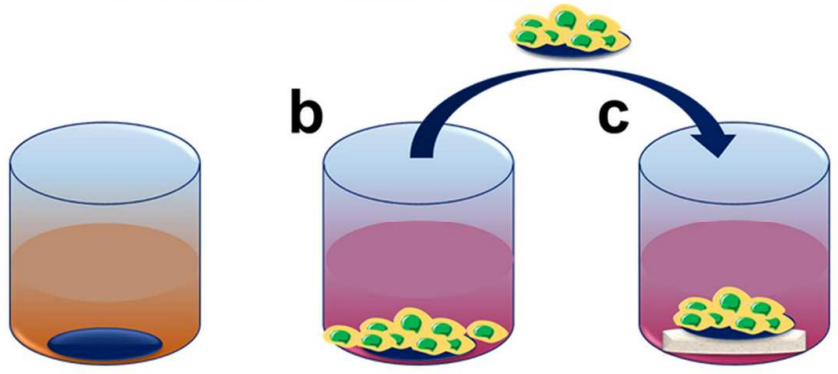

Figure S1. Illustration of the methodology for the direct and indirect cell cultures. For indirect cell cultures, the cells were cultured on glass coverslips that were placed on top of the material surface. Glass corevslips were preconditioned for 4 hours in FBS (a) and subsequently $20 \times 10^{3}$ cells/well (SaOS-2) or $5 \times 10^{3}$ cells/well (rMSCs) were seeded and cultured overnight (b). The glass coverslips were then transferred to new 24- well plates and placed on top of the material (c). 


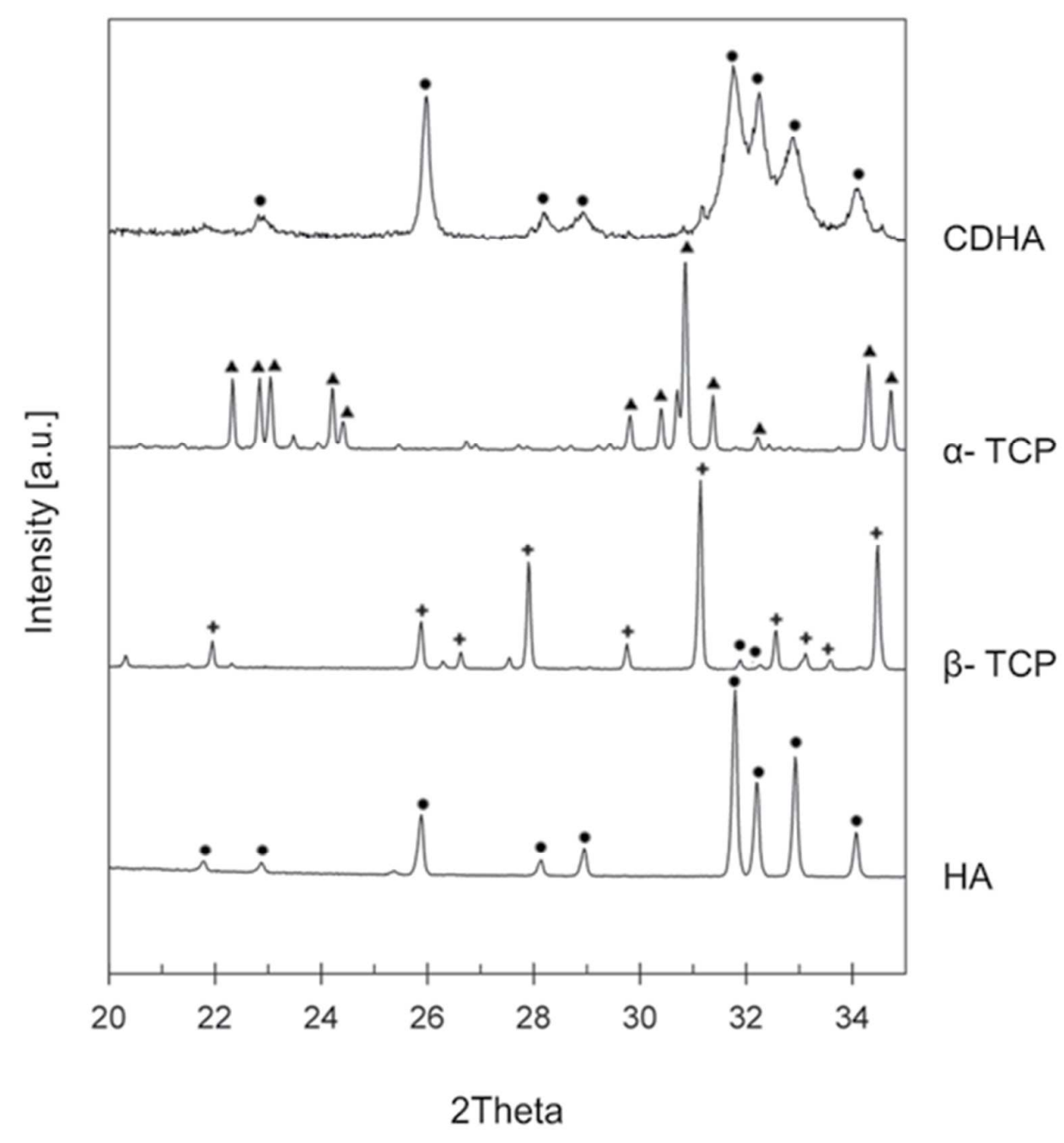

Figure S2. XRD patterns of obtained CaPs. XRD were compared with the Joint Committee on Powder Diffraction Standards for (•) HA (JCPDS 82-1943), (^) $\alpha$-TCP (JCPDS 09-0348) and (+) $\beta$-TCP (JCPDS 70-2065). 


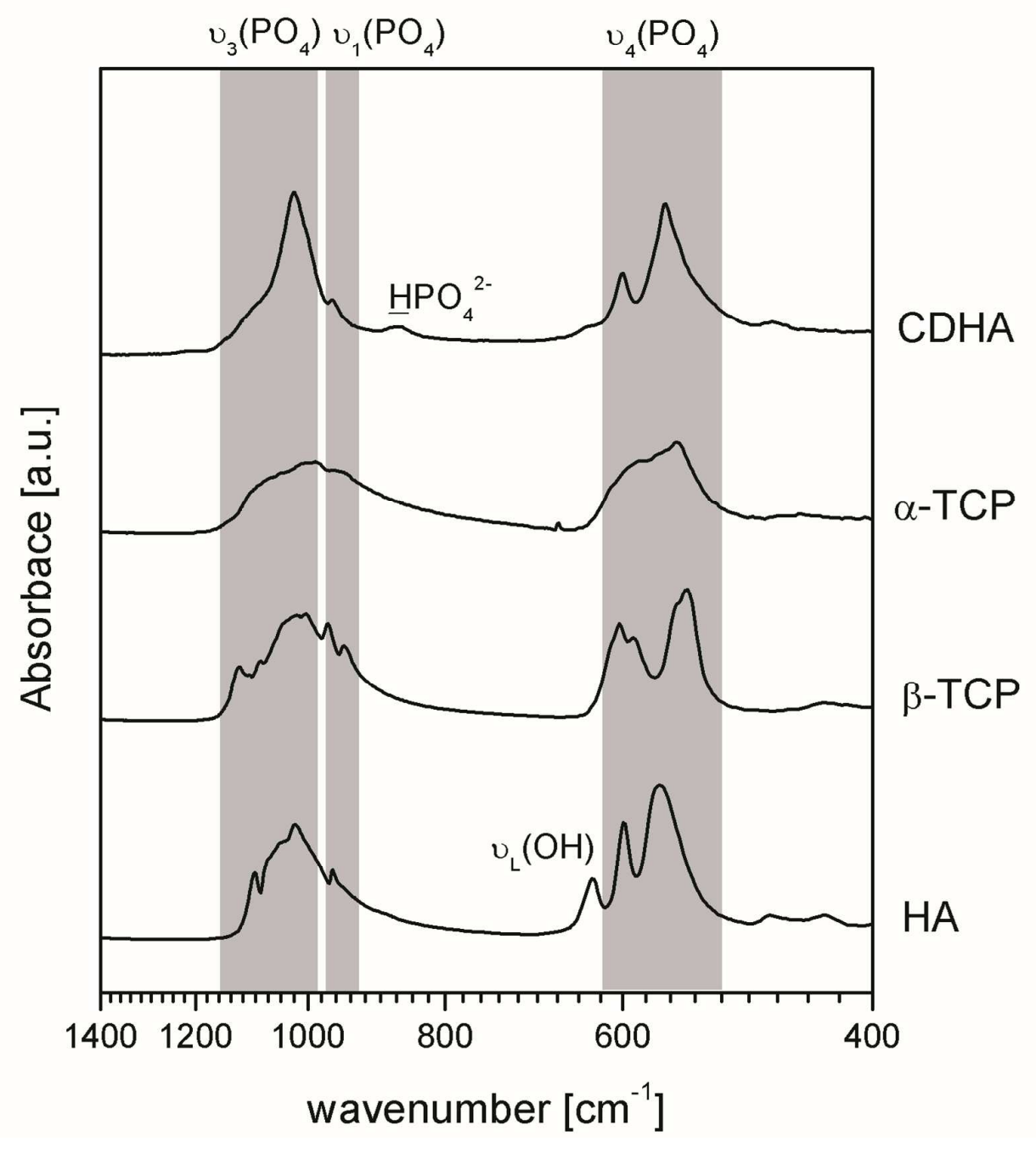

Figure S3. Characteristic FTIR spectra for the different CaPs in the vibration range: 400-1400 $\mathrm{cm}^{-1}$. Band assignation was done following the works by Drouet et al. and Carrodeguas et al. ${ }^{1,2}$ 


\section{References}

1. Drouet C. Apatite formation: why it may not work as planned, and how to conclusively identify apatite compounds. Biomed Res Int 2013, ID490946, 2013

2. Carrodeguas R.G., De Aza S. $\alpha$-Tricalcium phosphate: Synthesis, properties and biomedical applications. Acta Biomater 7(10), 3536, 2011 